\title{
The bivalve pump
}

\section{Barker Jørgensen ${ }^{1}$, Per Famme ${ }^{2}$, H. Saustrup Kristensen ${ }^{3}$, Poul S. Larsen ${ }^{3}$, F. Møhlenberg ${ }^{4} \&$ H. U. Riisgård ${ }^{2}$}

\author{
${ }^{1}$ Zoophysiological Laboratory A, August Krogh Institute, Universitetsparken 13, DK-2100, Copenhagen Ø, Denmark \\ ${ }^{2}$ Biological Institute, Odense University, Campusvej 55, DK-5230 Odense M, Denmark \\ ${ }^{3}$ Fluid Mechanics Department, Technical University of Denmark, DK-2800 Lyngby, Denmark \\ ${ }^{4}$ Marine Pollution Laboratory, National Agency of Environmental Protection, Kavalergården 6, DK-2920 Charlottenlund, \\ Denmark
}

\begin{abstract}
A filter feeding bivalve, represented by the mussel Mytilus edulis, is modelled as a pump, consisting of the bands of lateral cilia along the gill filaments, and a system of afferent and efferent canals. The relation between pump pressure $\Delta \mathrm{H}_{\mathrm{p}}$ and pumping rate $\mathrm{V}$ was approached through studies of the relations between system resistances and $\mathrm{V}$. The most important resistances distinguished were the frictional resistance in the canal system $\Delta \mathrm{H}_{\mathrm{f}}$, the exit loss $\Delta \mathrm{H}_{\mathrm{ex}}$ and the back pressure $\Delta \mathrm{H}_{12}$, imposed on the pump as a means to study the performance characteristics of the gill system. Removal of the laterofrontal cirri from the flow path by treatment with serotonin did not measurably affect the frictional resistance, but the cirri presumably constituted a flow-rate-independent resistance $\Delta \mathrm{H}_{1}$, arising from their beating against the flow. Thus, in steady state, $\Delta \mathrm{H}_{\mathrm{p}}=\Delta \mathrm{H}_{\mathrm{i}}+\Delta \mathrm{H}_{\mathrm{ex}}+\Delta \mathrm{H}_{12}+\Delta \mathrm{H}_{\mathrm{ll}}$. $\Delta \mathrm{H}_{\mathrm{r}}$ and $\Delta \mathrm{H}_{12}$ were linear functions of $\mathrm{V}$, whereas $\Delta \mathrm{H}_{\mathrm{ex}}$ was a quadratic function of $\mathrm{V}$. At values of $\mathrm{V}$ up to the maximum flow rates, $\Delta \mathrm{H}_{1}$ and $\Delta \mathrm{H}_{12}$ dominated the system resistance, and the pump characteristic was therefore approximately linear. The interfilament canals and the exhalant siphon presumably constitute the major resistances, in an optimally pumping 'standard' $35 \mathrm{~mm}$ mussel, thus constituting head losses of about $0.4 \mathrm{~mm}$ and $0.5 \mathrm{~mm} \mathrm{H} \mathrm{H}_{2} \mathrm{O}$, respectively. $\Delta \mathrm{H}_{1\}}$ amounted to $\leqslant 0.4 \mathrm{~mm} \mathrm{H}_{2} \mathrm{O}$. The operating point at zero back pressure was estimated at about $1.4 \mathrm{~mm} \mathrm{H} \mathrm{H}_{2} \mathrm{O}$. Removal of the laterofrontal cirri from the flow path drastically decreased the efficiency with which $\leqslant 6 \mu \mathrm{m}$ algal particles were retained by the gills, but it had no or little effect on the retention of $14 \mu \mathrm{m}$ particles, supporting previous indications that the laterofrontal cirri do not act as sieves of the through current, but rather as modulators in the process of particle retention. Power output of the $35 \mathrm{~mm}$ mussel at zero back pressure was $14 \mu \mathrm{W}$, only slightly lower than the maximum of $15 \mu \mathrm{W}$. The work done by the pump constituted about $1.5 \%$ of the total aerobic metabolic rate of the mussel.
\end{abstract}

\section{INTRODUCTION}

Filter feeding bivalves process large amounts of ambient water by means of the gills to acquire the food needed. An extensive literature deals with the amounts of water pumped through the gills and the efficiency with which suspended particles are retained, but little has been done to elucidate the properties of the pump (Jørgensen 1983, Jørgensen et al. 1984). Knowledge about the bivalve pump is essential not only for the understanding of the function of the gills as a pump, but also for the understanding of the filtering mechanism. It was generally accepted that the laterofrontal cirri on the gill filaments filtered the water entering the interfilament canals. This conception is now questioned, and it is suggested that the water largely bypasses the- cirral filters (Jørgensen
1983). In order to understand the function of the cirri we must therefore know the relative importance of intracirral and intercirral pathways for the water. We have studied the properties of the bivalve pump and analysed factors that determine pump pressure and pumping capacity as well as efficiency of particle retention. Special attention was paid to the nature and magnitude of the resistance offered by the laterofrontal cirri to the through current.

\section{MATERIAL AND METHODS}

Mussels Mytilus edulis L. were collected from the shore near the Biological Station at Bøgebjerg, Funen, Denmark. The mussels were kept in aquaria with flowing, unfiltered seawater of 16 to $18 \% \mathrm{~S}$. The set-up 


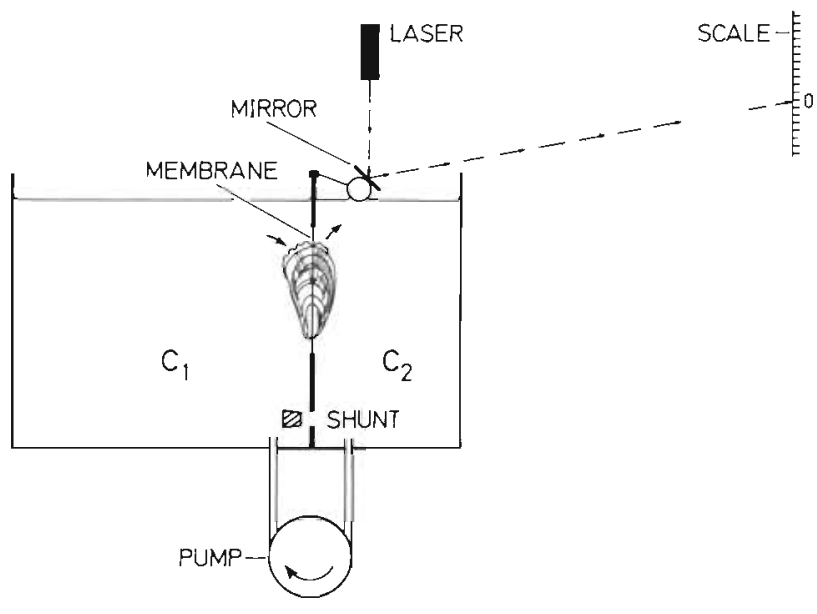

Fig. 1. Diagram of set-up used for direct measurement of pumping rates in Mytilus edulis

used in this work for direct measurements of pumping rates at various hydrostatic pressures imposed between exit and inlet is shown diagrammatically in Fig. 1. A $5 \mathrm{l}$ aquarium was divided into 2 chambers $\left(\mathrm{C}_{1}\right.$ and $\left.\mathrm{C}_{2}\right)$ by a silicone rubber membrane in which a slit had been cut. The mussel was inserted into the slit so that the membrane separated the inhalant current from the exhalant current. A shunt connected the 2 chambers when open. The water level in the exhalant chamber $\left(\mathrm{C}_{2}\right)$ was monitored with a laser beam striking a mirror that was fixed on a tethered floating ping-pong ball. The mirror reflected the laser beam onto a scale situated about $8 \mathrm{~m}$ from the mirror, a deflection of $1 \mathrm{~cm}$ on the scale corresponding to a $0.1 \mathrm{~mm}$ change in water level in $C_{2}$. When the mussel pumped water from $C_{1}$ to $\mathrm{C}_{2}$ with the shunt closed a pressure difference developed which could be fixed at any selected value by adjusting the calibrated peristaltic pump that pumped water from $\mathrm{C}_{2}$ to $\mathrm{C}_{1}$ (Famme et al. 1986). The efficiency with which particles of various sizes were retained was determined by counting added algal particles in samples taken at the inhalant and exhalant openings (Møhlenberg \& Riisgård 1978). Pure algal cultures were used as sources of particles, including Nanochloris sp., about $2.5 \mu \mathrm{m}$ in diameter, Isochrysis sp., about $3.5 \mu \mathrm{m}$, Rhodomonas sp., about $5.5 \mu \mathrm{m}$, and Thalassiosira sp., about $14 \mu \mathrm{m}$. Number and size distributions of particles in the water samples were determined by means of the Elzone electronic particle Counter, model $80 \mathrm{xy}$, fitted with a $38 \mu \mathrm{m}$ orifice tube. After the experiments, shell lengths were measured and gill areas of the mussels were determined by means of an Abbe drawing apparatus. Finally, the dry mass of the soft parts of the body was determined.

\section{RESULTS AND DISCUSSION}

\section{Overall system and pump characteristics}

A filter-feeding bivalve is modelled as a pump and a system of afferent and efferent canals (Fig. 2 bottom). The bands of lateral cilia (lc), which constitute the pump proper, are located in the upstream ends of the interfilament canals. In reality the pump consists of a large number of small pumps arranged in parallel. Other active ciliated elements and structures are considered to be part of the canal system in regard to their contributions to pressure changes. These include the laterofrontal cirri (lf) which, although positioned so close to the bands of lateral cilia that oscillating flow interaction may be expected (Jørgensen 1983), are not considered to be part of the pump. The canal system includes the flow path from the inhalant opening (io) through the mantle cavity $(\mathrm{mc}$ ) to the entrance to the interfilament canals (ifc) on the upstream side of the
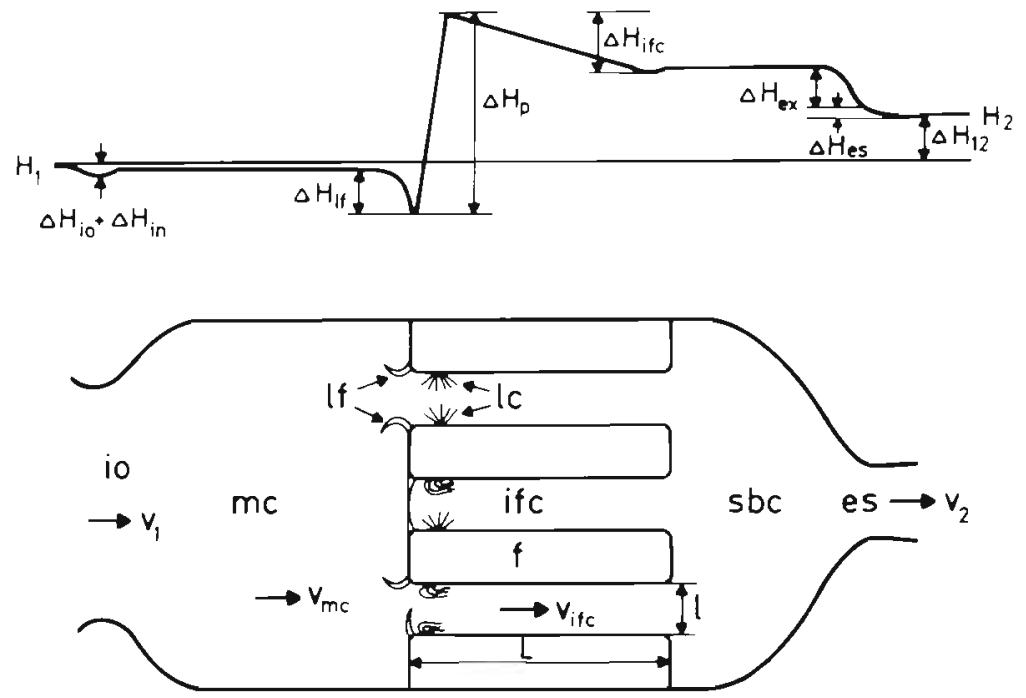

Fig. 2. Mytilus edulis. Diagrams of the mussel pump (bottom) and of pressure heads, $\Delta H_{\text {, (top) }}$ (see Fig. 3) along the flow path. es: exhalant siphon; f: filament; ifc: interfilament canal io: inhalant opening; 1 : interfilament distance; L: length of interfilament canal; lc: band of lateral cilia; lf: laterofrontal cirri; mc: mantle cavity; sbc: suprabranchial cavity; $v_{1}$ : flow velocity in inhalant opening; $v_{2}$ : flow velocity in exhalant siphon; $v_{\text {ifc }}$ : flow velocity in interfilament canals; $v_{m c}$ : flow velocity in mantle cavity 
pump, and the interfilament canals, demibranchial lumina, suprabranchial cavity (sbc) and exhalant siphon (es) on the downstream side.

A pump is characterized by the relation between pressure rise (say in column height of fluid) delivered by the pump, $\Delta \mathrm{H}_{p}$, and flow rate, $\mathrm{V}$. This relation, the pump characteristic, is not directly accessible for analysis, but it may be approached indirectly through studies of the relations between pressure resistances exerted by the system, $\Delta \mathrm{H}_{\text {sys }}$ and flow rate, the system characteristic. In steady state the pump pressure equal the system resistance, $\Delta \mathrm{H}_{\mathrm{p}}=\Delta \mathrm{H}_{\text {sys }}$.

In a filter feeding bivalve, such as a mussel, the system resistance can be resolved into several components. The most important are the frictional resistance in the canal system $\Delta \mathrm{H}_{f}$, the exit loss $\Delta \mathrm{H}_{\mathrm{ex}}$, and the back pressure $\Delta H_{12}$, all of which are flow-rate dependent. To these may be added a flow-rate independent resistance, $\Delta \mathrm{H}_{\mathrm{lf}}$, arising from the beating of the laterofrontal cirri directed against the flow as deduced from experiments (see below) (Fig. 2 top). Thus

$$
\Delta \mathrm{H}_{\mathrm{p}}=\Delta \mathrm{H}_{\mathrm{f}}+\Delta \mathrm{H}_{\mathrm{ex}}+\Delta \mathrm{H}_{12}+\Delta \mathrm{H}_{\mathrm{lf}} .
$$

The relations between component resistances and flow rate, the component characteristics, together with the back pressure response, define the pump characteristic.

\section{Shape of system characteristics}

Flow through mussels is laminar (Jergensen et al. 1986), and the frictional loss in the canal system is thus presumably a linear function of the flow rate, that is

$$
\Delta \mathrm{H}_{\mathrm{f}}=\mathrm{C}_{\mathrm{f}} \mathrm{V}
$$

where $C_{f}$, the frictional coefficient, is the slope of $\Delta H_{f}$ versus flow rate $\mathrm{V}$ (Fig. 3).

The exit loss is given by $\Delta H_{e x}=v_{2}^{2} / 2 g$, where $v_{2}$ is the velocity at the exit of the exhalant siphon; $g$ is the acceleration of gravity. $v_{2}=V / A_{e x}$, where $A_{e x}$ is the cross sectional area of the exhalant siphon. The relation may therefore be written

$$
\Delta \mathrm{H}_{\mathrm{ex}}=\mathrm{C}_{\mathrm{ex}} \mathrm{V}^{2}
$$

where $C_{e x}=\left(2 \mathrm{gA}_{\mathrm{ex}}^{2}\right)^{-1}$. Because $\Delta \mathrm{H}$ is a quadratic function of $\mathrm{V}$, the relative importance of the exit loss increases with the flow rate.

All of the kinetic energy may be considered lost for the jet of water issuing into the ambient at hydrostatic pressure $\mathrm{H}_{2}$. The sink flow from the upstream stagnation state at hydrostatic pressure $\mathrm{H}_{1}$ to the inhalant opening, however, may be considered to be loss-free (or any frictional contribution may be included in $\Delta \mathrm{H}_{\mathrm{f}}$ ).

The back pressure is the positive hydrostatic pressure difference between exit and inlet, $\mathrm{H}_{2}-\mathrm{H}_{1}=$ $\Delta \mathrm{H}_{12}$ (Fig. 2 top). In nature it depends on the ambient flow pattern and is presumably insignificant. In the laboratory, arbitrary positive or negative values of $\Delta \mathrm{H}_{12}$ may be externally imposed as a means to study the performance characteristics of the gill system.

The nature of the relation between imposed back pressure and flow rate, the back pressure-flow characteristic, cannot be predicted theoretically, but it was found that within experimental uncertainty the relation can be described by the linear function (Fig. 3, see also Famme et al. 1986)

$$
\Delta \mathrm{H}_{12}=\Delta \mathrm{H}_{12}^{\circ}-\mathrm{C}_{12} \mathrm{~V}
$$

where $\Delta \mathrm{H}_{12}^{\circ}$ is the intersection of the ordinate (at zero pumping rate); and $\mathrm{C}_{12}=\Delta \mathrm{H}_{12}^{\circ} / \mathrm{V}^{\circ}$ indicates the slope, $\mathrm{V}^{\circ}$ being the intersection of the abscissa (at zero back pressure).

Eq. (1) may now be written

$$
\Delta \mathrm{H}_{\mathrm{p}}=\Delta \mathrm{H}_{12}^{o}-\left(\mathrm{C}_{12}-\mathrm{C}_{\mathrm{f}}\right) \mathrm{V}+\mathrm{C}_{\mathrm{ex}} \mathrm{V}^{2}+\Delta \mathrm{H}_{1 \mathrm{f}} .
$$

The pump characteristic is thus determined by 2 linear and 1 quadratic term. At conditions where the exit loss is small compared with other resistance losses the pump head pressure thus approximates a linear function of flow rate (Fig. 3 ; Eq. 5). A linear characteristic is to be expected for a low Reynolds number viscous pump.

\section{Elements of the system characteristic}

In order to determine the position of the pump characteristic the contributions of the various terms of the system characteristic should be evaluated.

Fig. 2 top shows schematically the variation of static pressure $\mathrm{H}$ along the flow path through a mussel subjected to back pressure $\Delta H_{12}$. Note that $H$ changes according to the Bernoulli equation for frictionless changes in local fluid velocity $v$, superimposed by decreases owing to friction and an increase at the level of the pump owing to its energy supply.

The frictional loss in the canal system includes several contributions, varying strongly in importance. Often their absolute values can only be estimated, with varying degrees of certainty. For the purpose of illustration the following discussion considers a 'standard' $35 \mathrm{~mm}$ Mytilus edulis, optimally pumping at $17^{\circ} \mathrm{C}$, having gill area $A_{g}=850 \mathrm{~mm}^{2}$, exhalant siphon area $A_{\text {ex }}=16 \mathrm{~mm}^{2}$, pumping rate $\mathrm{V}=1 \mathrm{ml} \mathrm{s}^{-1}$, hence velocities (see Fig. 2 bottom) $\mathrm{v}_{\mathrm{mc}}=1.18 \mathrm{~mm} \mathrm{~s}^{-1}, \mathrm{v}_{\mathrm{lfc}}=$ $2 \times 1.18=2.36 \mathrm{~mm} \mathrm{~s}^{-1}$, and $\mathrm{v}_{2}=62.5 \mathrm{~mm} \mathrm{~s}^{-1}$. The area of the inhalant opening is about $80 \mathrm{~mm}^{2}$. 


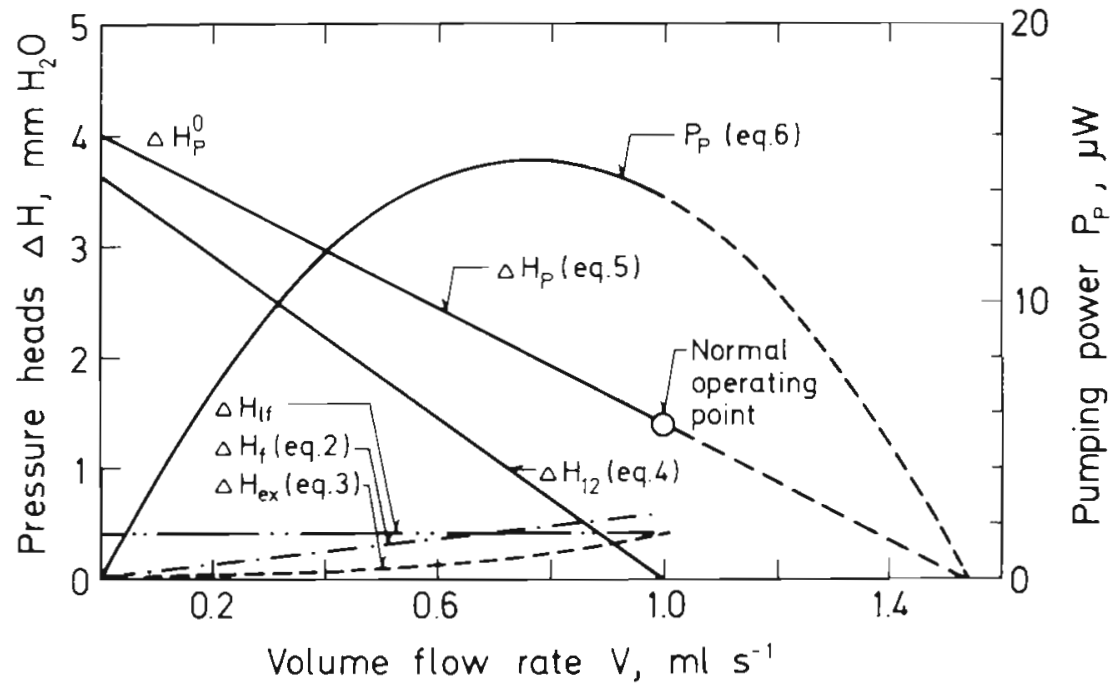

Fig. 3. Mytilus edulis. Schematic characterization of the mussel pump. Headflow characteristics for friction $\left(\Delta \mathrm{H}_{\mathrm{f}}\right)$, exit flow $\left(\Delta \mathrm{H}_{\mathrm{ex}}\right)$, back pressure $\left(\Delta \mathrm{H}_{12}\right)$ and pump pressure $\left(\Delta \mathrm{H}_{\mathrm{p}}\right) ; \Delta \mathrm{H}_{\mathrm{f}}$ : flow-independent pressure head; $\mathrm{P}_{\mathrm{p}}$ : flow ratepumping power characteristic. (See text for further explanation)
Interfilament canals

The interfilament canals are of relatively simple geometry, permitting realistic estimates to be made of frictional losses. The head loss is calculated for fully developed laminar flow between stationary parallel plates, spaced a distance $l$ apart and of length $\mathrm{L}$, for $\Delta \mathrm{H}_{\mathrm{ifc}}=12 \mathrm{vvL} / \mathrm{g} l^{2}$, where $v$ is the kinematic viscosity ( $=1.1 \times 10^{-6} \mathrm{~m}^{2} \mathrm{~s}^{-1}$ at $17^{\circ} \mathrm{C}$ ), and $v$ is the mean velocity (Walshaw \& Jobson 1979, p. 183). Values of $\mathrm{L}=200 \mu \mathrm{m}, l=40 \mu \mathrm{m}$, and $\mathrm{v}=2.36 \mathrm{~mm} \mathrm{~s}^{-1}$ yield $\Delta \mathrm{H}_{\text {ifc }}=0.44 \mathrm{~mm} \mathrm{H}_{2} \mathrm{O}$.

\section{Exhalant siphon}

The exhalant siphon is believed to be the most important adjustable system resistance (Foster-Smith 1976a). The siphonal aperture is oval, the long axis of which is about 3.5 times the short axis in the fully open state. In the $35 \mathrm{~mm}$ standard mussel the short axis is $2.4 \mathrm{~mm}$, yielding a cross-sectional area of $16 \mathrm{~mm}^{2}$. The length of the siphon was estimated to be $3 \mathrm{~mm}$. For a mean velocity of $62.5 \mathrm{~mm} \mathrm{~s}^{-1}$, corresponding to a Reynolds number of about 200, laminar flow is developing and the frictional pressure drop is estimated from boundary layer theory to be $\Delta \mathrm{H}_{\mathrm{es}}=2.66\left(\mathrm{vv} \mathrm{v}^{3} \mathrm{~L}\right)^{1 / 2} / \mathrm{dg} \sim$ $0.14 \mathrm{~mm} \mathrm{H}_{2} \mathrm{O}$. This estimate is based on a hydraulic diameter $(4 \times$ area/perimeter $)$ of $\mathrm{d}=3.3 \mathrm{~mm}$ and an average core velocity of $\mathrm{v} \sim 86 \mathrm{~mm} \mathrm{~s}^{-1}$. As boundary layers (of displacement thickness $\delta_{1} \sim 1.72(v \mathrm{~L} / \mathrm{v})^{1 / 2}$ ) develop along the walls of the siphon the core velocity increases considerably. Note that boundary layer friction is not linear in flow rate but depends on $\mathrm{V}^{3 / 2}$. A term of this form should formally appear in Eq. (5). In addition to the frictional head loss in the siphon, the kinetic energy of the issuing jet $\Delta \mathrm{H}_{\mathrm{ex}}=\mathrm{v}^{2} / 2 \mathrm{~g}=0.38$ $\mathrm{mm} \mathrm{H}_{2} \mathrm{O}$ constitutes a loss.

Indeed, a small change in hydraulic diameter $d$ of the siphon has a pronounced effect on the head loss. For constant volume flow, continuity implies $\mathrm{v} \sim \mathrm{d}^{-2}$, hence from the foregoing expressions for head loss, $\Delta \mathrm{H}_{\mathrm{es}} \sim \mathrm{d}^{-4}$ and $\Delta \mathrm{H}_{\mathrm{ex}} \sim \mathrm{d}^{-4}$.

Inhalant opening and other canals

Head losses over the inhalant opening(io), as well as the mantle cavity and suprabranchial cavity, are presumably insignificant compared with the exhalant siphon because of the large cross-sectional areas at these regions of the flow system.

A boundary-layer analysis following that given above gives $\Delta \mathrm{H}_{\mathrm{io}} \sim 0.004 \mathrm{~mm} \mathrm{H}_{2} \mathrm{O}$ (based on mantle edge length $3 \mathrm{~mm}$, area $80 \mathrm{~mm}^{2}$ and hydraulic diameter $6.5 \mathrm{~mm}$ ). If all of the kinetic energy of the weak jet $\left(\sim 20 \mathrm{~mm} \mathrm{~s}^{-1}\right)$ entering the mantle cavity is considered to be lost this would add $\Delta \mathrm{H}_{i n}=0.02 \mathrm{~mm} \mathrm{H}_{2} \mathrm{O}$.

In the normally functioning mussel, as well as in mussels pumping water against a positive pressure head, the demibranchs are inflated because of the higher pressure inside the lumen of the demibranchs than in the mantle cavity. In their inflated state the demibranch lumina presumably offer little frictional resistance to the water flow. When negative pressure is imposed on the total pump system the back pressureflow characteristic becomes very steep and flow rate may approach independency of pressure head (Famme et al. 1986). This may be correlated with collapse of the flaccid gills, resulting in a strongly increased intraluminal resistance. 
pump is to increase the beat frequency of the lateral cilia (Aiello 1960, Gosselin 1961). At $10^{-6} \mathrm{M}$ serotonin, a concentration that strongly stimulates the beat frequency of the lateral cilia (Table 1), the back pressureflow characteristic of the mussel was little affected (Fig. 4 and Table 2). At $10^{-5} \mathrm{M}$ serotonin the characteristic was displaced somewhat toward larger values of head and flow, having a nearly unchanged slope (Table 2).

In view of the discussion of the overall system and pump characteristics, a shift of the back pressure-flow characteristic may be interpreted in the following manner.

Firstly, an increased beat frequency of the lateral cilia may change the pump characteristic toward greater head and capacity, but not necessarily preserving the slope. (The simple model of a viscous moving belt pump, however, would preserve the slope if the internal pump friction were ignored, $\Delta \mathrm{H}_{\mathrm{p}}^{\circ}\left(=\Delta \mathrm{H}_{12}^{\circ}+\Delta \mathrm{H}_{11}\right)$ and $\mathrm{C}_{\mathrm{p}}$ in Eq. (5) being increased by the same factor; including internal pump friction would give rise to a steeper characteristic of the stimulated pump).

Secondly, locking of the laterofrontal cirri in positions bent over the frontal surfaces of the filaments eliminates their contribution to the pressure loss. If this contribution were that of plain viscous friction it would vary linearly with flow rate and, taken separately, tilt the characteristic to a lesser steepness through an unchanged value of $\Delta \mathrm{H}_{\mathrm{p}}^{\circ}$. Such an effect was not revealed in the experiments. If, on the other hand, the laterofrontal cirri were not considered to represent a passive viscous resistance but rather an active resistance, in the form of a pump opposing the throughcurrent, their arrest would cause a shift of the back

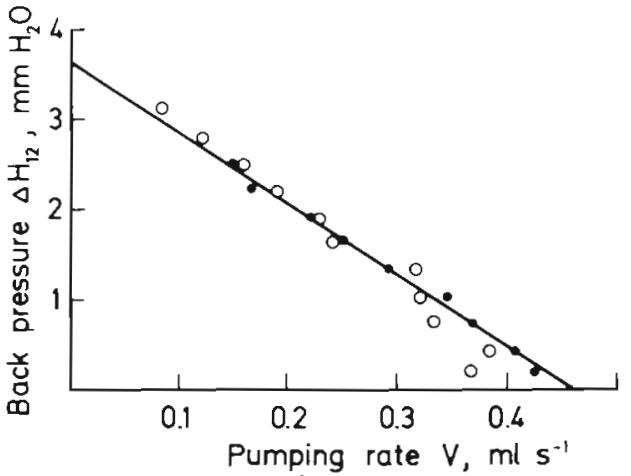

Fig. 4. Mytilus edulis. Back pressure-flow characteristic in a mussel pumping seawater (•) and seawater containing serotonin at a concentration of $10^{-6} \mathrm{M}(0)$. Line indicates regression in seawater (see \#5, Table 2)

pressure-flow characteristic. Pumps having very flat characteristics (nearly constant head independent of flow) can be perceived. Such a performance, alone or along with a changed cilia pump characteristic, can explain the observed shifts in Table 2 .

It has been assumed that stimulation with serotonin does not affect other parameters, such as the geometry of interfilament canals or the exhalant siphon. On this assumption, and ignoring furthermore the possible effects of serotonin on the pump performance, the experimental results give us an upper limit to the head loss caused by the laterofrontal cirri, $\Delta \mathrm{H}_{1,}$, of about $0.4 \mathrm{~mm} \mathrm{H}_{2} \mathrm{O}$ independent of flow rate.

In the $35 \mathrm{~mm}$ standard Mytilus edulis the total head loss at normal conditions of zero back pressure may thus be estimated as about $1.4 \mathrm{~mm} \mathrm{H}_{2} \mathrm{O}$ which consequently equals the pump head at zero back pressure (Table 3).

Table 2. Mytilus edulis. Effect of serotonin on linear relation between back pressure $\Delta \mathrm{H}_{12}$ and pumping rate $\mathrm{V}$ in fully open mussels, as described by the equation $\Delta \mathrm{H}_{12}\left(\mathrm{~mm} \mathrm{H}_{2} \mathrm{O}\right)=a-b \mathrm{~V}\left(\mathrm{ml} \mathrm{s}^{-1}\right)$. $\Delta \mathrm{H}_{12}^{0}$ : back pressure at zero pumping rate; $\mathrm{V}^{\circ}$ : pumping rate at zero back pressure; $r$ : regression coefficient

\begin{tabular}{|c|c|c|c|c|c|c|c|c|}
\hline$\#$ & $\begin{array}{l}\text { Length } \\
(\mathrm{mm})\end{array}$ & $\begin{array}{c}\text { Serotonin } \\
\left(\text { conc. } \mathrm{mol} \mathrm{l}^{-1}\right)\end{array}$ & $\begin{array}{c}a=\Delta \mathrm{H}_{12}^{\mathrm{o}} \\
\left(\mathrm{mm} \mathrm{H} \mathrm{H}_{2} \mathrm{O}\right)\end{array}$ & $b$ & r & $\mathrm{n}$ & $\begin{array}{c}V^{o} \\
\left(\mathrm{ml} \mathrm{s}^{-1}\right)\end{array}$ & $\left({ }^{\circ} \mathrm{C}\right)$ \\
\hline 11 & 36 & $\begin{array}{c}0 \\
10^{-6} \\
10^{-5} \\
5 \times 10^{-5}\end{array}$ & $\begin{array}{l}3.6 \\
4.6 \\
5.0 \\
4.7\end{array}$ & $\begin{array}{l}5.70 \\
7.38 \\
7.08 \\
6.06\end{array}$ & $\begin{array}{l}-0.949 \\
-0.832 \\
-0.938 \\
-0.965\end{array}$ & $\begin{array}{r}10 \\
9 \\
14 \\
14\end{array}$ & $\begin{array}{l}0.63 \\
0.62 \\
0.71 \\
0.78\end{array}$ & 17 \\
\hline 12 & 39 & $\begin{array}{c}0 \\
0 \\
10^{-6} \\
10^{-6}\end{array}$ & $\begin{array}{l}5.0 \\
4.5 \\
3.3 \\
4.0\end{array}$ & $\begin{array}{r}13.14 \\
9.90 \\
8.40 \\
8.52\end{array}$ & $\begin{array}{l}-0.933 \\
-0.934 \\
-0.981 \\
-0.967\end{array}$ & $\begin{array}{l}11 \\
11 \\
11 \\
11\end{array}$ & $\begin{array}{l}0.38 \\
0.45 \\
0.39 \\
0.47\end{array}$ & 17 \\
\hline 5 & 34 & $\begin{array}{c}0 \\
10^{-6}\end{array}$ & $\begin{array}{l}3.6 \\
4.0\end{array}$ & $\begin{array}{r}7.80 \\
p<0.05 \\
9.42\end{array}$ & $\begin{array}{l}-0.995 \\
-0.984\end{array}$ & 11 & 0.46 & 8 \\
\hline 8 & 41 & $\begin{array}{c}0 \\
10^{-5}\end{array}$ & $\begin{array}{l}2.6 \\
3.4\end{array}$ & $\begin{array}{r}3.00 \\
p<0.02 \\
3.72\end{array}$ & $\begin{array}{l}-0.985 \\
-0.998\end{array}$ & 7 & 0.87 & 8 \\
\hline
\end{tabular}


Table 3. Distribution of head losses $(\Delta \mathrm{H})$ along the flow path from entry to exit in an optimally pumping $35 \mathrm{~mm}$ 'standard' mussel at $17^{\circ} \mathrm{C}$

\begin{tabular}{|c|c|}
\hline Location & $\begin{array}{c}\Delta \mathrm{H} \\
\left(\mathrm{mm} \mathrm{H}_{2} \mathrm{O}\right)\end{array}$ \\
\hline \multicolumn{2}{|l|}{ Inhalant opening } \\
\hline friction, $\Delta \mathrm{H}_{10}$ & 0.004 \\
\hline kinetic energy, $\Delta H_{\llcorner n}$ & 0.02 \\
\hline Laterofrontal cirri, $\Delta \mathrm{H}_{\mathrm{lf}}$ & 0.4 \\
\hline Interfilament canals, $\Delta \mathrm{H}_{\text {uic }}$ & 0.44 \\
\hline Demibranch lumina and suprabranchial cavity & $\sim 0$ \\
\hline \multicolumn{2}{|l|}{ Exhalant siphon } \\
\hline friction, $\Delta \mathrm{H}_{\mathrm{es}}$ & 0.14 \\
\hline kinetic energy, $\Delta \mathrm{H}_{\mathrm{ex}}$ & 0.38 \\
\hline Total & 1.38 \\
\hline
\end{tabular}

While the total head loss cannot be measured, experimental data are available for head losses across inhalant and exhalant siphons. By an early technique Foster-Smith (1976b) measured these to be $0.05 \mathrm{~mm}$ $\mathrm{H}_{2} \mathrm{O}$ and 0.1 to $0.25 \mathrm{~mm} \mathrm{H}_{2} \mathrm{O}$, respectively. But with an improved technique Jones \& Allen (1986) obtained values an order of magnitude higher, viz. $0.54 \pm 0.18$ (SD) $\mathrm{mm} \mathrm{H}_{2} \mathrm{O}$ and $1.23 \pm 0.48 \mathrm{~mm} \mathrm{H}_{2} \mathrm{O}$, respectively. Our present estimates based on boundary layer friction and accounting for kinetic energy loss in jets yield at the most $0.02 \mathrm{~mm} \mathrm{H}_{2} \mathrm{O}$ and $0.52 \mathrm{~mm} \mathrm{H}_{2} \mathrm{O}$, respectively (Table 3).

Now, reconsider the head loss calculation for the exhalant siphon with a $0.9 \mathrm{~mm}$ O.D. static probe used by Jones \& Allen inserted through the siphon. Including the displacement thickness of the boundary layer on the probe it causes an area blockage of about $1.50 \mathrm{~mm}^{2}$, raising the core velocity to about $96 \mathrm{~mm} \mathrm{~s}^{-1}$. The friction from all boundary layers amounts to $0.19 \mathrm{~mm} \mathrm{H}_{2} \mathrm{O}$ and the kinetic energy loss to $0.47 \mathrm{~mm}$ $\mathrm{H}_{2} \mathrm{O}$, a total of $0.66 \mathrm{~mm} \mathrm{H}_{2} \mathrm{O}$, which exceeds by $27 \%$ that of the undisturbed mussel. The error associated with insertion of the same probe into the inhalant siphon is estimated to be about $20 \%$.

These estimates assume no change in volume flow or geometry of the siphon, and are based on the foregoing data of our standard $35 \mathrm{~mm}$ mussel. The lack of data on geometry and flow of the test mussels used by Jones \& Allen does not permit conclusions other than the inherent discrepancy between probe indication and actual pressure in an undisturbed mussel. The magnitude of the discrepancy, found to be about 20 to $30 \%$ for our sample calculation, will depend on geometry and flow.

It is unexpected that Jones \& Allen found the pressure drop across the inhalant siphon to approach half that across the exhalant siphon, considering the many times larger cross-sectional area of the inhalant opening.
The component-flow relations constituting the system characteristic are drawn to approximate scale in Fig. 3, which also shows the resultant pump characteristic. The contribution of non-linear terms (boundary layer friction and $\Delta \mathrm{H}_{\text {ex }}$, Fig. 3, Eq. 3) declines to insignificance with increasing back pressure, leaving the pump characteristic practically linear (Fig. 3, Eq. 5). It may be seen that at $\Delta \mathrm{H}_{12}=0$, the operating point of the pump, as determined by $\Delta \mathrm{H}_{f}, \Delta \mathrm{H}_{\mathrm{ex}}$ and $\triangle \mathrm{H}_{1 \mathrm{f}}$, amounts to about $1.4 \mathrm{~mm} \mathrm{H}_{2} \mathrm{O}$.

\section{Efficiency of particle retention}

Concurrently with measuring effects of serotonin on the back pressure-flow characteristic we also recorded effects on the efficiency with which the gills retained particles, algae, of various sizes. It may be seen from Fig. 5 that with increasing concentration of serotonin in the ambient water the gills of Mytilus edulis gradually became more leaky to the smaller particles, correlated with the decreasing angle of beat of the laterofrontal cirri. Larger particles, about $14 \mu \mathrm{m}$ in diameter, corresponding to about one third the distance between neighbouring filaments, were still efficiently retained when the laterofrontal cirri were absent from the entrance to the interfilament canals.

It is thus indicated that the laterofrontal cirri do not act as sieves of the through current, but that they act as modulators in the process of particle retention, raising its efficiency for the smaller particles.

\section{Other parameter effects on characteristic}

In order to compare back pressure-flow characteristics of individual mussels, and to study effects of temperature and other factors, flow rates were expressed

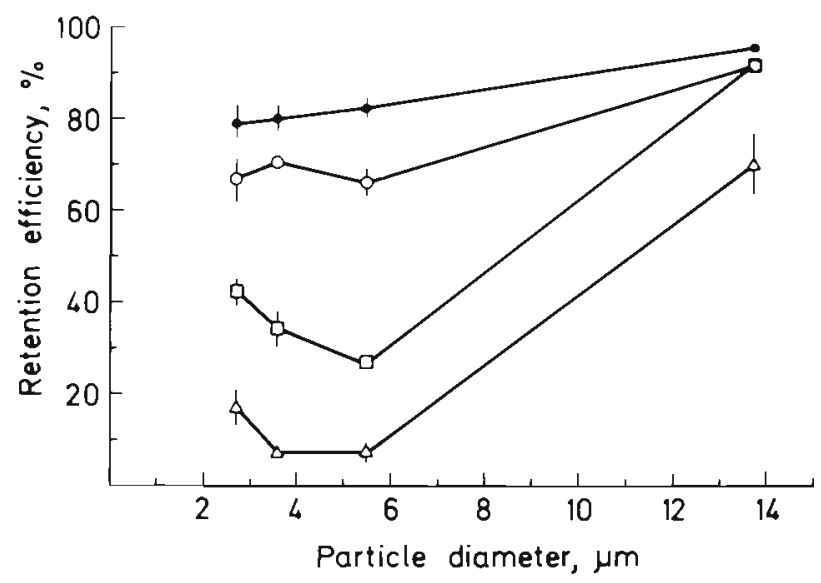

Fig. 5. Mytilus edulis. Effect of serotonin on the efficiency with which the gill retains particles differing in size. (๑) Seawater; (O) $10^{-6} \mathrm{M}$ serotonin; $(\square) 5 \times 10^{-6}$ serotonin; ( $\left.\Delta\right) 1$ to 5 $\times 10^{-5} \mathrm{M}$ serotonin 
per unit gill surface area. This appears reasonable since pumping capacity is expected to be proportional to gill area, while pump head and resistances may be insensitive to size.

Table 4 shows area specific maximum flow rates and maximum pump pressures as measured in 23, 30 to $44 \mathrm{~mm}$ long, fully open mussels at about 17 and $8^{\circ} \mathrm{C}$. During the experiments at $17^{\circ} \mathrm{C}$, in August, it was evident that pumping capacity varied with the behavior. Optimally open mussels with the mantle edges diverging pumped significantly more water and tended to produce higher pressure heads than those exhibiting parallel-oriented mantle edges.

The fully open state with expanded, diverging mantle edges is typical of undisturbed mussels. Measurements made on mussels in this state are, presumably, representative for optimal conditions in nature. This implies that at $17^{\circ} \mathrm{C}$ undisturbed mussels pump a mean of $6.3 \mathrm{ml} \mathrm{min}^{-1}$ water per $\mathrm{cm}^{2}$ gill surface. The mean flow velocity normal to the gill surface is thus about $1 \mathrm{~mm} \mathrm{~s}^{-1}$, as used in our 'standard' case.

When evaluating effects of temperature on the pump, mussels in similar states should be compared. At a temperature of $8^{\circ} \mathrm{C}$, recordings of $\mathrm{V}$ and $\Delta \mathrm{H}_{12}$ are only available from mussels exhibiting parallel mantle edges. These mussels pumped less water and produced larger pressure heads than did the corresponding group at $17^{\circ} \mathrm{C}$ (Table 4 ). The ratio $\mathrm{V}^{\circ} / \Delta \mathrm{H}_{12}^{\circ}$ was thus substantially affected by a change in temperature.

This ratio, the reciprocal of the slope in the back pressure-flow characteristic, expresses how much the pumping rate decreases per unit pressure head imposed on the system. At $17^{\circ} \mathrm{C}$ the flow rate decreased about $1.35 \mathrm{ml} \mathrm{cm}{ }^{-2} \mathrm{~min}^{-1}$ for each $1 \mathrm{~mm}$ $\mathrm{H}_{2} \mathrm{O}$ increase in back pressure, whereas at $8^{\circ} \mathrm{C}$ in mussels in a comparable state the rate was $0.78 \mathrm{ml}$ $\mathrm{cm}^{-2} \mathrm{~min}^{-1}$ per $1 \mathrm{~mm} \mathrm{H}_{2} \mathrm{O}$. The decrease thus amounted to $42 \%$. Such effect of temperature may result from increased viscous resistance. Increased resistance due to increased viscosity of the water may account for $22 \%$, the kinematic viscosity $v$ being $1.1 \times$ $10^{-6} \mathrm{~m}^{2} \mathrm{~s}^{-1}$ at $17^{\circ} \mathrm{C}$ and $1.38 \times 10^{-6} \mathrm{~m}^{2} \mathrm{~s}^{-1}$ at $8^{\circ} \mathrm{C}$, leaving half of the decrease unaccounted for.

\section{Energetics of the pump}

The power output from the pump varies with volume flow and head as determined by the operating point which is changed by changing the externally imposed back pressure $\Delta \mathrm{H}_{12}$. Assuming a linear pump characteristic $\Delta \mathrm{H}_{\mathrm{p}}=\Delta \mathrm{H}_{\mathrm{p}}^{o}-\mathrm{C}_{\mathrm{p}} \mathrm{V}$, where $\Delta \mathrm{H}_{\mathrm{p}}^{\circ}$ is the intersection of the ordinate and $C_{p}=\Delta H_{p}^{o} / V^{o}$ indicates the slope, $\mathrm{V}^{\circ}$ being the nominal intersection of the $\mathrm{ab}$ scissa, indicating the potential maximal flow rate or $\mathrm{V}_{\max }^{\mathrm{O}}$, the power curve is a parabola,

$$
P_{p}=\rho g\left(\Delta H_{p}^{o}-C_{p} V\right) V,
$$

reaching its maximum at $\mathrm{V}=0.5 \mathrm{~V}_{\max }^{\mathrm{pax}}$ (Fig. 3, Eq. 6).

For our sample case of Mytilus edulis at $\Delta \mathrm{H}_{12}=0$ and the values $\Delta \mathrm{H}_{12}^{\circ}=3.6 \mathrm{~mm} \mathrm{H}_{2} \mathrm{O}$ and $\Delta \mathrm{H}_{\mathrm{lf}}=0.4 \mathrm{~mm}$ $\mathrm{H}_{2} \mathrm{O}$ it is easy to find $\Delta \mathrm{H}_{\mathrm{p}}^{\circ}=4.0 \mathrm{~mm} \mathrm{H}_{2} \mathrm{O}$ and $\mathrm{C}_{\mathrm{p}}=2.6$ $\mathrm{mm} \mathrm{H}_{2} \mathrm{O}$ per $\mathrm{ml}^{-1}$. Thus, the pumping power becomes $P_{p}=14 \mu \mathrm{W}$. This is not much less than the maximum value $P_{p \text {, max }}=15 \mu \mathrm{W}$, which occurs at $\mathrm{V} \cong 0.77 \mathrm{ml} \mathrm{s}^{-1}$ corresponding to $\triangle \mathrm{H}_{12}=0.83 \mathrm{~mm} \mathrm{H}_{2} \mathrm{O}$.

It is interesting to note that the normal operating point is close to that of maximum power. The experiments with imposed back pressure thus did not expose the mussel to conditions requiring excessive pump power, as would have been the case had the normal operating point been closer to that of $V_{\text {max }}^{p}$ (would occur for lower internal friction). Conversely, assuming an internal friction far greater than suggested by our sample case, the normal operating point would fall below that of maximum power.

The kinetic energy of the jet leaving the siphon at unrestricted flow accounts for $0.38 \mathrm{~mm} \mathrm{H}_{2} \mathrm{O} \sim 28 \%$ of the total work done, corresponding to the share of $\Delta \mathrm{H}_{\mathrm{ex}}$ in $\Delta \mathrm{H}_{\mathrm{p}}$ (Table 3).

The work done by the pump may be compared with the total energy expenditure of the mussel, as expressed by the rate of oxygen consumption. According to Hamburger et al. (1983) the $35 \mathrm{~mm}$ mussel, dry mass of the soft tissue amounting to $0.21 \mathrm{~g}$, consumes $0.169 \mu \mathrm{l} \mathrm{h} \mathrm{h}^{-1}$ of oxygen. If we assume that $1 \mathrm{ml} \mathrm{O}$ corresponds to $1.92 \times 10^{8} \mathrm{erg}$ this corresponds to an aerobic metabolic rate of $9013 \mathrm{erg} \mathrm{s}^{-1}$ or $900 \mu \mathrm{W}$ of which the work of the pump constitutes $1.6 \%$.

Table 4. Relation between maximum back pressure $\left(\Delta \mathrm{H}_{12}^{\circ}\right)$ and gill area specific pump capacity ( $\left.\mathrm{V}^{\circ}\right)$ in fully open mussels

\begin{tabular}{|c|c|c|c|c|c|}
\hline $\begin{array}{l}\text { Orientation of } \\
\text { mantle edges }\end{array}$ & $\mathrm{n}$ & $\stackrel{t}{\left.{ }^{\circ} \mathrm{C}\right)}$ & $\left(\mathrm{ml} \mathrm{cm} \mathrm{V}^{\circ} \mathrm{min}^{-1}\right)$ & $\begin{array}{c}\Delta \mathrm{H}_{12}^{\circ} \\
\left(\mathrm{mm} \mathrm{H} \mathrm{H}_{2} \mathrm{O}\right)\end{array}$ & $\mathrm{V}^{0} / \Delta \mathrm{H}_{12}^{\mathrm{o}}$ \\
\hline Parallel and diverging & 14 & 17 & $5.0 \pm 0.43$ & $3.4 \pm 0.21$ & $1.52 \pm 0.16$ \\
\hline Diverging & 6 & & $\begin{array}{r}6.3 \pm 0.68 \\
p=0.01\end{array}$ & $\begin{array}{c}3.8 \pm 0.30 \\
\text { NS }\end{array}$ & $\begin{array}{c}1.73 \pm 0.25 \\
\text { NS }\end{array}$ \\
\hline Parallel & 8 & & $\begin{array}{r}4.1 \pm 0.25 \\
p<0.01\end{array}$ & $\begin{array}{r}3.1 \pm 0.24 \\
p<0.05\end{array}$ & $\begin{array}{r}1.35 \pm 0.19 \\
p<0.01\end{array}$ \\
\hline Parallel & 9 & 8 & $3.0 \pm 0.13$ & $3.7 \pm 0.12$ & $0.78 \pm 0.033$ \\
\hline
\end{tabular}




\section{LITERATURE CITED}

Aiello, E. L. (1960). Factors affecting ciliary activity on the gill of the mussel Mytilus edulis. Physiol. Zool. 33: 120-135

Batchelor, G. K. (1967). An introduction to fluid dynamics. Cambridge University Press, London

Dral, A. D. G. (1967). The movements of the latero-frontal cilia and the mechanism of particle retention in the mussel (Mytilus edulis L.). Neth. J. Sea Res. 3: 391-422

Famme, P., Riisgărd, H. U., Jørgensen, C. B. (1986). On direct measurements of pumping rates in the mussel Mytilus edulis. Mar Biol 92: 323-327

Foster-Smith, R. L. (1976a). Some mechanisms for the control of pumping activity in bivalves. Mar. Behav. Physiol. 4: $41-60$

Foster-Smith, R. L. (1976b). Pressures generated by the pumping mechanism of some ciliary filter-feeders. J. exp. mar. Biol. Ecol. 25: 199-206

Gosselin, R. E. (1961). The cilio-excitatory activity of serotonin. J. cell. comp. Physiol. 58: 17-26

Hamburger, K., Møhlenberg, F., Randløv, A., Riisgård, H. U. (1983). Size, oxygen consumption and growth in the mussel Mytilus edulis. Mar. Biol. 75: 303-306

Jorgensen, C. B. (1975). On gill function in the mussel Mytilus edulis L. Ophelia 13: 187-232

Jargensen, C. B. (1976). Comparative studies on the function of gills in suspension feeding bivalves, with special reference to effects of serotonin. Biol. Buil. mar. biol. Lab., Woods Hole 151: 331-343

Jørgensen, C. B. (1983). Fluid mechanical aspects of suspension feeding. Mar. Ecol. Prog. Ser. 11: 89-103
Jørgensen, C. B., Kiørboe, T., Møhlenberg, F., Riusgård, H. U. (1984). Ciliary and mucus-net filter feeding, with special reference to fluid mechanical characteristics. Mar Ecol. Prog. Ser. 15: 283-292

Jørgensen, C. B., Mohlenberg, F., Sten-Knudsen, O. (1986). Nature of relation between ventilation and oxygen consumption in filter feeders. Mar. Ecol. Prog. Ser. 29: 73-88

Jones, H. D., Allen, J. R. (1986). Inhalant and exhalant pressures in Mytilus edulis and Cerastoderma edule. J. exp. mar. Biol. Ecol. 98: 231-240

Møhlenberg, F., Riisgård, H. U. (1978). Efficiency of particle retention in 13 species of suspension feeding bivalves. Ophelia 17: 239-246

Moore, H. J. (1971). The structure of the latero-frontal cirri on the gills of certain lamellibranch molluscs and their role in suspension feeding. Mar. Biol. 11: 23-27

Owen, G. (1974). Studies on the gill of Mytilus edulis: the eulaterofrontal cirri. Proc. R. Soc. (Ser. B) 187; 83-91

Sanderson, M. J., Dirksen, E. R., Satir, P. (1985). The antagonistic effects of 5-hydroxytryptamine and methylxanthine on the gill cilia of Mytilus edulis. Cell Motil. 5: 293-309

Silvester, N. R., Sleigh, M. A. (1984). Hydrodynamic aspects of particle capture by Mytilus. J. mar. biol. Ass. U. K. 64 : 859-879

Tamada, K., Fujikawa, H. (1957). The steady two-dimensional flow of viscous fluid at low Reynolds numbers passing through an infinite row of equal parallel circular cylinders. Q. J. Mech. appl. Math. 10: 425-432

Walshaw, A. C., Jobson, D. A. (1979). Mechanics of fluids. 3rd edn. Longman, London

This article was submitted to the editor; it was accepted for printing on September 11, 1986 